\title{
SINKRETISME DAN SIMBOLISME TRADISI SELAMATAN KEMATIAN DI DESA PURWOSARI, KULON PROGO
}

\author{
Oleh: Suwardi
}

\begin{abstract}
Abstrak
Bila suatu tradisi lama, yang berakar pada kepercayaan kuno (animisme) dapat bertahan, dipertahankan, atau bahkan dilestarikan di era informasi yang bersifat mengglobal pada waktu ini, maka patut diduga bahwa tradisi tersebut haruslah mempunyai seperangkat parameter yang diyakini oleh komunitasnya memiliki nilai dan makna yang tinggi. Hingga saat ini, masih banyak desa-desa di Jawa yang memiliki berbagai tradisi seperti itu. Salah satu desa tersebut adalah Desa Purwosari, Kecamatan Girimulyo, Kulon Progo, dan salah satu tradisi termaksud adalah tradisi kematian.
\end{abstract}

Tulisan ini bertujuan untuk mengangkat parameter kekuatan atau ketahanan keberadaan tradisi selamatan kematian di Desa Purwosari termaksud dengan cara mendeskripsikan ikatan emosional atau ikatan batin antara warga komunitas dan tradisi selamatan kematian yang mereka lakukan. Aspek khusus yang hendak digunakan sebagai pisau analisis adalah sinkretisme dan simbolisme pada butir-butir tindakan dalam rangkaian selamatan kematian yang ada mulai dari geblag hingga nуewu.

Hasil analisis terhadap rangkaian tindakan tradisi selamatan kematian di Desa Purwosari, Kecamatan Girimulyo. Kulon Progo menunjukkan adanya sinkretisme Hindu-Jawa dengan Islam, khususnya yang terkait dengan adanya bentuk doa (donga) dan pemujaan kepada roh orang yang telah meninggal di lain pihak. Pemujaan ini tampak diyakini oleh komunitas tradisi yang bersangkutan sebagai cara mencapai keselamatan, kesejahteraan, keamanan, ketenteraman, dan kedamaian hidup di dunia, serta bebas dari gangguan alau ancaman yang bersumber pada adanya keharmonisan hubungan antara yang memuja (komunitas tradisi) dan yang dipuja (roh orang-orang yang telah meninggal). Kelompok khusus dari komunitas ini, yang masih teguh menjalani dan menghayati tradisi termaksud, adalah kelompok yang dikenal dengan sebulan kaum abangan. 


\section{A. Pendahuluan}

Masyarakat Jawa di waktu ini, di pulau Jawa khususnya, yang memiliki sistem transportasi, komunikasi, dan pengembangan ilmu serta teknologi modern dan telah pula lama bersentuhan dan berinteraksi secara langsung dengan budaya-budaya global, masih melaksanakan, menghayati, dan bahkan mempertahankan berbagai tradisi lama yang nota bene sangat berbeda atau bahkan berlawanan dengan prinsip-prinsip modern dan modernisasi dalam hidup dan kehidupan. Salah satu tradisi termaksud adalah tradisi selamatan yang terkait dengan peristiwa kematian seseorang warga komunitas penganut tradisi tersebut.

Sampai saat ini, tradisi selamatan yang terkait dengan peristiwa kematian seseorang masih tetap diuri-uri atau dipelihara banyak warga masyarakat Jawa, khususnya di pedesaan. Tradisi ini didukung baik oleh masyarakat Jawa pedesaan yang masih tradisional, Jawa transisi yang sedang berubah ke arah masyarakat kota, maupun oleh sebagian masyarakat Jawa perkotaan yang telah mengenyam pendidikan tinggi. Masyarakat Desa Purwosari, Kecamatan Girimulyo, Kulon Progo, misalnya, masih melaksanakan dan bahkan nguri-uri tradisi selamatan kematian di desanya. Desa ini memiliki warga masyarakat yang sangat heterogin dalam hal kepercayaan. Warga masyarakat desa ini ada beragama Islam, Kristen, Katolik, dan ada pula kelompok yang disebut sebagai kaum Abangan. Masyarakat di daerah ini telah banyak yang terpelajar, namun banyak di antara mereka yang masih 'taat' melaksanakan, menghayati, dan bahkan mempertahankan keeradaan tradisi selamatan pada upacara kematian.

Secara garis besar, tradisi selamatan kematian adalah bentuk pemujaan roh orang yang telah meninggal dengan harapan tetap terjadi hubungan yang "harmonis" antara warga masyarakat yang masih hidup dan roh-roh orang yang telah meninggal. Masam dan urutan selamatan kematian yang tergolong selalu dilaksanakan adalah sebagai beikut.

1. Geblag atau selamatan setelah penguburan

2. Nelung dina atau selamatan setelah tiga hari kematian

3. Mitung dina atau selamatan setelah tujuh hari kematian

4. Matangpuluh dina atau selamatan setelah 40 hari kematian

5. Nyatus dina atau selamatan setelah 100 hari kematian 
6. Mendhak sepisan atau selamatan setelah satu tahun kematian

7. Mendhak pindho atau selamatan setelah dua tahun kematian

8. Nyewu atau selamatan setelah seribu hari kematian

Berikut ini akan diuraikan satu persatu bentuk dan fungsi dari tindakan-tindakan selamatan tersebut serta aspek sinkretisme dan simbolisme yang dikandung dari sudut pandang warga dan pelaku tradisi yang bersangkutan.

\section{B. Geblag atau Selamatan Setelah Penguburan}

Selamatan kematian setelah penguburan (geblag) oleh warga masyarakat di Desa Purwosari disebut ngesur tanah. Cara menentukan waktu selamatan (hari dan pasaran) ngesur tanah digunakan rumus jisarji yang berarti hari ke satu dan pasaran ke satu atau harus dilaksanakan pada hari itu juga, atau tidak boleh ditunda.

Selamatan ngesur tanah merupakan awal dari rangkaian selamatan kematian. Selamatan ini dilakukan sebagai upaya pihak ahli waris mengiringkan kepergian roh orang yang telah mati. Beberapa saat setelah seseorang meninggal roh yang bersangkutan diyakini oleh komunitas tradisi mempersiapkan diri untuk meninggalkan keluarganya menuju alam kubur. $\mathrm{Hal}$ ini sejalan dengan pendapat Bratawidjaja (1993:136) bahwa selamatan ngesur tanah memiliki makna yang terkait dengan "kepergian" roh orang yang mening gal. Pemaknaan semacam ini dapat dirunut dari kata ngesur tanah yang berasal kata sur yang merupakan kependekan dari kata ngesur, yang berarti memperluas, dan kata tanah berarti bumi. Ngesur tanah dimaknai sebagai upaya agar roh orang yang meninggal mendapatkan tempat atau tanah kubur yang luas, yang dalam bahasa Jawa disebutkan sebagai jembar kubure.

Ngesur tanah juga dimaksudkan untuk 'menjinakkan' roh-roh lain yang ada di lingkungan dan atau sekitar kuburan. Roh-roh ini diharapkan tidak akan mengganggu orang yang menggali kubur, menguburkan jenazah, dan roh dari orang yang baru saja dikuburkan itu sendiri. Dengan melaksanakan selamatan ngesur tanah oleh penganut tradisi, penggali kubur dan yang menguburkan jenazah tadi telah meminta permisi (amit-amit) kepada pada para roh lain dengan harapan bahwa roh-roh tersebut tidak akan mengganggu. Dengan demikian selamatan ngesur tanah memiliki fungsi sosial-spiritual. 
Selamatan ngesur tanah juga dimaksudkan untuk memberi penghormatan kepada roh orang yang meninggalnya sendiri berupa upaya untuk memberikan tindakan penyempurnaan. Ini berarti ahli waris masih mempunyai tanggung jawab terhadap kepergian roh yang bersangkutan agar memperoleh kesempurnaan. Para ahli waris berkeyakinan bahwa roh orang yang baru saja meninggal masih berada di tempat tidur. Roh ini perlu dicarikan tempat yang layak jika nanti telah menempati alam kubur.

Dengan kata lain, selamatan ngesur tanah merupakan tindakan untuk menyempurnakan roh dan jasat (raga) orang yang meninggal. Melalui selamatan ini dimaksudkan agar roh dan jasat orang yang mati tidak mendapatkan siksa kubur yang berat. Tanda bahwa jasad orang mati tadi adhem ayem di alam kubur adalah jasad akan dan dapat melebur menjadi tanah. Karena jasad manusia berasal dari tanah maka akhirnya harus kembali menjadi tanah. Untuk hal ini, konteks budaya Jawa menganggap orang yang mati tersebut telah purna dalam mengawali perjalanannya menuju sangkan paraning dumadi.

Roh dan jasad yang mencapai kesempurnaan akan mendapatkan tempat yang semestinya di alam kubur. Roh dan jasad tersebut tidak akan panas di kubur. Tanah kubur tidak akan menghimpitnya. Sebagai tanda dari tidak terhimpitnya roh dan jasad adalah jika tanah kubur yang bersangkutan tidak mingkup (menjadi sempit) dan tidak jemblong/ambrol (terbuka). Dalam konteks budaya Jawa, hal ini dikatakan dengan sebutan jasad dan roh dapat lepas parane jembar kubure.

Saji-sajian yang disediakan dalam selamatan ngesur tanah menggunakan ubarampe sesaji sega-asahan, tumpeng pungkur (tumpeng yang dibelah dua dan diletakkan ungkur-ungkuran atau bertolak belakang), sega wuduk atau sega rasul nasi diberi garam, nasi gurih, apem, dan ingkung ayam. Semua sajian ini menurut Ki Padmosusastro (1907:88-89) jumlahnya harus ganjil, misalkan 3, 5, 7, dan sembilan. Jika yang meninggal anak-anak, sesaji yang digunakan tidak perlu memakai apem dan tumpeng, dan cukup diganti dengan degan (kelapa muda).

Maksud dari sajian diharuskan ganjil masih perlu ditelusuri lebih lanjut. Masyarakat Jawa percaya bahwa bilangan ganjil memiliki nilai "istimewa" dalam arti tidak dapat dibagi-bagi. Hal ini melambangkan 
perjalanan roh dan proses kembalinya jasad untuk menuju pada suatu titik, yaitu titik kasampurnan (kesempurnaan). Kesempurnaan bermakna satu, yaitu identik dengan bilangan ganjil. Maksudnya, pelaku tradisi meyakini bahwa kesempurnaan hanyalah milik Tuhan Yang Maha Esa. Manusia dalam kondisi semacam ini diharapkan selalu ngudi kasampurnan atau berupaya mencapai kesempurnaan sejati, yakni mendekatkan diri kepada Tuhan atau bahkan menurut konsep mistik Jawa, dapat menunggal (menyatu) dengan Tuhan.

Masing-masing ubarampe (perlengkapan sesaji) memiliki makna simbolis. Untuk itu akan diuraikan satu per satu sebagai berikut:

(1) Tumpeng pungkur mempunyai makna simbolis agar roh yang telah meninggal tidak lagi memikirkan keduniawian dan keluarga yang ditinggalkannya. Roh harus ngungkurake donyane atau membelakangi dunia fana dan berpisah dengan badan kasar serta nafsunya (napsu patang prakara). Di pihak lain, keluarga yang ditinggalkan tidak perlu lagi mengingat-ingat yang sudah mati. Tumpeng sebagai lambang seksual (alat kelamin) laki-laki. Karena itu jika seseorang telah meninggal dunia, maka nafsu seksual pun juga telah mati. Tumpeng juga melambangkan perpisahan antara suksma sejati dengan badan kasar dan nafsunya. Suksma sejati kembali pada asalnya (Suhardi, 1986:44). Pengertian "tidak perlu lagi mengingat-ingat" orang yang telah mati diartikan bahwa keluarga yang ditinggalkan tidak perlu terlalu sedih yang berkepanjangan. Kesusahan karena kematian anggota keluarga adalah wajar, artinya manusiawi, namun tidak perlu harus dibesar-besarkan.

(2) Sega asahan (ambeng) adalah nasi yang dikemas berbentuk bulat dan agak mbenunuk (seperti bukit yang rendah). Bentuk semacam ini melambangkan alat seksual (alat kelamin) seorang wanita. Jika seseorang telah meninggal maka nafsu seksualnya sudah tiada lagi. Dengan kata lain bahwa yang bersangkutan sudah sampai ke tingkat ambeng (ngambang) atau hilang sama sekali nafsu seksualnya.

(3) Sekul wuduk (sega rasul) adalah nasi yang diberi garam. Nasi ini rasanya asin sebagai simbol keilmuan Rasul yang sangat tinggi dan luas sehingga ada peribahasa bahwa orang yang berilmu adalah orang yang banyak makan garam. Nasi ini oleh Modin (Kaum Rois) sering diikrarkan sebagai tanda penghormatan kepada Rasulullah dengan harapan bahwa roh orang yang meninggal termasuk golongan Rasul, sehingga kelak di akhirat akan 
mendapatkan safaat Rasul. Kepercayaan semacam ini merupakan perpaduan antara Islam dengan kepercayaan Hindu-Jawa.

(4) Nasi gurih adalah nasi bersantan yang diberi warna kuning keemasan. Warna ini sebagai lambang kemenangan. Dengan ubarampe, ahli waris mengharapkan agar anggota keluarga yang meninggal dunia kelak mendapatkan kemenangan di akhirat. Artinya, jika nanti yang bersangkutan ditimbang amalnya, amal baiknya akan menang (lebih berat) dibanding amal jeleknya.

(5) Ingkung ayam adalah ayam utuh yang dibentuk seperti posisi wanita duduk timpuh atau seperti posisi orang sedang duduk pada saat shalat. Bentuk semacam ini menggambarkan sikap orang yang sedang manekung (bersemadi). Hal ini sesuai dengan makna kata ingkung yang berasal dari kata ing (ingsun) dan kung (manekung). Kata ingsun berarti aku dan kata manekung berarti berdoa dengan penuh khidmat. Dengan demikian ingkung merupakan perwujudan sikap ahli waris yang dengan sungguh-sungguh memohon doa agar anggota keluarganya yang telah meninggal diampuni segala dosa-dosanya dan mendapatkan tempat yang semestinya.

Selamatan ngesur tanah biasanya dihadiri oleh tetangga yang ikut menguburkan jenazah. Setelah penguburan selesai, para pelayat diminta segera kembali ke rumah ahli waris untuk melaksanakan selamatan. Selamatan diawali dengan pembakaran kemenyan oleh Modin. sebelumnya telah diberi mantra atau doa yang isinya, antara lain, memohonkan ampun bagi orang yang meninggal dunia. Prosesi semacam ini merupakan gabungan antara Hindu Jawa dengan Islam.

Komunitas tradisi termaksud beranggapan bahwa selamatan ngesur tanah merupakan suatu 'keharusan' untuk dilaksanakan. Karena itu para pendukungnya enggan dan takut meninggalkan selamatan termaksud. Pada umumnya, mereka takut tertimpa akibat tertentu dikemudian hari. Jadi, tujuan utama selamatan adalah agar terciptanya kondisi ora ana apa-apa. Kondisi semacam ini oleh Geertz (1987:58) dikatakan sebagai keadaan slamet (selamat) yaitu kondisi sejahtera, selamat, sehat, dan makmur. Keadaan ini merupakan situasi dan kondisi yang aman dalam arti tidak ada gangguan dari alam maupun gangguan adikodrati.

Tujuan seperti termaksud di atas cukup beralasan karena sejalan 
dengan pendapat Suhardi (1986:38) yang menyatakan bahwa orang Jawa memang memiliki keyakinan bahwa hidup manusia sudah ditentukan secara pasti oleh Tuhan. Pada saat terjadi suatu peristiwa, seperti kematian, orang Jawa memandang adanya saat-saat yang gawat atau saat-saat yang kritis, yaitu saat di mana individu yang bersangkutan dan kerabat dekatnya berada dalam keadaan lemah yang sifatnya suci atau sakral. Keadaan yang gawat itu dapat menimbulkan bahaya sosial, misalnya gangguan tatanan kosmos atau ancaman terhadap keseimbangan komunitas. Sumber terjadinya bahaya ini diyakini berasal dari kekuatan adikodrati. Untuk mengantisipasi bahaya itu para pendukungnya lalu mengadakan selamatan (slametan).

\section{Nelung dina atau Selamatan Setelah Tiga Hari Kematian}

Cara menentukan waktu selamatan hari dan pasaran nelung dina digunakan rumus lusarlu, yaitu hari ketiga dan pasaran ketiga. Maksudnya, jika ada seseorang yang meninggal dunia pada hari Jum' at Kliwon waktu selamatan nelung dina jatuh pada hari Minggu Paing. Pelaksanakan selamatan biasanya dilakukan malam hari menjelang hari dan pasaran ke tiga atau melem (menjelang) Minggu Paing.

Selamatan nelung dina dimaksudkan sebagai upaya ahli waris untuk penghormatan kepada roh orang yang meninggal. Dalam kaitan ini orang Jawa berkeyakinan bahwa roh orang yang meninggal masih berada di dalam rumah. Namun roh tersebut sudah tidak berada di tempat tidur lagi. Roh sudah mulai berkeliaran untuk mencari jalan agar dengan mudah meninggalkan rumah dan anggota keluarganya. Oleh karena roh itu masih berada di dalam rumah, kadang-kadang juga masih sering hadir berkali-kali di sekitar keluarga. Kehadiran roh tersebut dapat berupa bayangan-bayangan (ketok-ketoken) atau ton-tonen oleh anggota keluarga. Ada juga roh yang masih memperlihatkan diri melalui mimpi anggota keluarga (ahli waris). Itulah sebabnya anggota keluarga dan terutama anak-anak sering ketakutan. Untuk menghindari ketakutan itu biasanya diadakan lek-lekan atau cegah wungon yang dihadiri oleh tetangga dan saudara. Acara ini sekaligus dimaksudkan untuk menghibur keluarga yang ditinggalkan (kesripahan).

Selamatan nelung dina juga berfungsi untuk menyempurnakan empat perkara yang disebut anasir hidup manusia, yaitu bumi, api, angin, dan air 
(Bratawidjaja, 1993:136). Untuk penyempurnaan anasir ini diadakan kenduri yang ubarampenya sama dengan selamatan ngesur tanah. Keunikan ubarampe selamatan nelung dina ini belum memakai ubarampe apem. Saji-sajian selamatan dalam kenduri nelung dina dimaksudkan untuk memberikan penghormatan kepada roh lain agar tidak mengganggu roh orang yang telah meninggal. Upaya semacam ini sesuai dengan penelitian Sularto dkk. (1982:41) yang isinya menjelaskan bahwa kebanyakan masyarakat Jawa masih tetap melestarikan kepercayaan lama yaitu tradisi pemberian sesajian kepada arwah dan makhluk halus (dhanyang-dhanyang). Selamatan semacam ini sering dikategorikan sebagai aktualisasi agama Jawa.

Kepercayaan tersebut di atas merupakan sinkretik antara kepercayaan animisme dengan Islam yang dipadukan secara rapi. Hal ini seperti dikemukakan oleh Geertz (1989:6) bahwa masyarakat Jawa sejak abad ke-15 telah menganut tradisi animisme yang merupakan perpaduan (sinkretis) antara unsur-unsur Hindu-Jawa dengan Islam. Bahkan Geertz dengan amat berani setelah meneliti di daerah Mojokuto (Jawa Timur), menyatakan bahwa tradisi selamatan pada ritus kematian lebih banyak dilakukan dengan cara memberi saji-sajian pada roh. Kegiatan selamatan semacam ini banyak dilakukan oleh kaum abangan dibanding oleh kaum santri dan priyayi.

\section{Mitung Dina atau Selamatan setelah Tujuh Hari Kematian}

Cara menentukan waktu selamatan hari dan pasaran mitung dina digunakan tusaro, yaitu hari ke ketujuh dan pasaran kedua. Maksudnya, jika orang meninggal dunia pada hari Jum' at Kliwon maka selamatan mitung dina jatuh pada hari Kemis Legi.

Selamatan mitung dina dimaksudkan untuk penghormatan terhadap roh. Setelah tujuh hari roh mulai keluar dari rumah. Itulah sebabnya secara simbolis ahli waris membukakan genting atau cendela agar sebelum selamatan dimulai agar roh orang yang meninggal dapat keluar dengan lancar dari rumah. Roh yang sudah keluar dari rumah akan berhenti sejenak di pekarangan atau berada di halaman sekitar (sajroning wangon). Untuk mempermudah perjalanan roh meninggalkan pekarangan ahli waris membantu dengan cara selamatan tahlilan, dan mendoakan.

Tahlil dilaksanakan selama 7 malam yang berupa bacaan (waosan 
kalimah tayibah). Kata tahlil berasal dari kata Arab hallala yang berarti membaca kalimat "Laailaha illallah" dengan tujuan mendoakan agar dosa orang yang meninggal diampuni. Pada malam terakhir, pembacaan tahlil ditutup dan sekaligus selamatan mitung dina. Penutupan tahlil dimaksudkan juga sebagai syukuran atas selesainya tahlil. Karena itu peserta kenduri diberi sodaqoh berupa bancakan yang berisi nasi dan lauk pauknya. Kata bancakan kemungkinan berasal dari tempat tumpeng pungkur yang dibuat dari anyaman bambu secara renggang. Anyaman semacam ini disebut ancak. Perkembangan selanjutnya berubah menjadi kata bancak.

Salah satu sajian atau ubarampe mitung dina yang unik adalah memakai apem dan pasung. Kata apem kemungkinan berasal dari kata Arab afufun yang artinya mohon ampun. Ubarampe ini disajikan dengnan maksud agar orang yang meninggal diampuni segala dosa-dosanya. Ubarampe apem berbentuk bulatan lepek seperti piring kecil. Bentuk ini mengandung makna sebagai alas jika orang yang meninggal nanti panas akan melewati ara-ara Ma'sar yang sangat lebar. Sebagai jodoh apem adalah pasung yang kemungkinan besar berasal dari perubahan bunyi kata payung. Pasung dibuat dari daun nangka yang dibentuk seperti payung atau dalam bahasa Jawa krama disebut songsong. Maksudnya, agar orang yang meninggal mendapatkan songsong (perlindungan) dari Tuhan.

Dengan sajian-sajian di atas, selamatan mitung dina dimaksudkan juga untuk menyempurnakan kulit dan kuku orang yang meninggal (Bratawidjaja, 1993:136). Pemaknaan demikian terkait dengan pengertian sangkan paran (asal-usul) badan wadhag manusia. Badan wadhag manusia berasal dari empat anasir (tanah, angin, air, api) baru dikatakan sempurna apabila telah diperingati dengan selamatan.

\section{E. Matangpuluh dina atau selamatan setelah $\mathbf{4 0}$ hari kematian}

Cara menentukan waktu selamatan hari dan pasaran matangpuluh dina digunakan rumus masarma, yaitu hari kelima dan pasaran kelima. Jika hari geblagnya Jum'at Kliwon, maka matangpuluh dina jatuh pada hari Selasa Wage. Tepatnya perhitungan yaitu setelah kurang lebih selapan (35 hari) atau atau selapan dina hari Jum' at Kliwon baru dicari hari Selasa Wage.

Tradisi selamatan matangpuluh dina dimaksudkan sebagai upaya untuk 
mempermudah perjalanan roh menuju ke alam kubur. Ahli waris membantu perjalanan itu dengan mengirim doa yaitu dengan bacaan tahlil dan selamatan. Ubarampe selamatan sama dengan sajian pada waktu mitung dina (Padmosusastro, 1907:88-89). Dengan ubarampe selamatan yang bermacammacam itu dimaksudkan sebagai sajian kepada roh dan jasad. Jasad yang harus disempurnakan adalah berupa darah, daging, sungsum, jeroan (isi perut), kuku, rambut, tulang, dan otot (Bratawidjaja, 1993:136).

Fungsi selamatan matangpuluh dina juga untuk memberi penghormatan kepada roh orang yang meninggal yang sudah mulai keluar dari pekarangan (sanjabaning wangon) dan akan menuju ke alam kubur. Pada saat ini roh sudah mulai bergerak sedikit demi sedikit menuju alam kubur. Roh mulai mencari jalan yang lurus dan bersih yaitu jalan mana yang ketika pemberangkatan jenazah sudah disapu. Jika jalannya sudah bersih maka tidak akan ada aral melintang untuk menuju alam kubur. Fungsi selamatan ini sesuai dengan esensi selamatan yang sebenarnya yaitu sebagai upaya pemujaan pada roh orang yang meninggal.

Hal ini seperti tersebut di atas dikemukakan oleh Koentjaraningrat (1974:268-269) bahwa di sekitar hidup manusia akan tinggal berbagai macam roh dari orang yang telah meninggal. Roh tersebut dapat mengganggu hidup manusia jika tidak dipuja atau dipelihara semestinya. Sebaliknya, roh juga dapat mendatangkan keberuntungan jika dipuja atau diberi selamatan. Bahkan menurut Baal (1987:89) bentuk religi tertua manusia adalah animism, yaitu kepercayaan adanya roh-roh orang yang telah meninggal. Hal ini sesuai dengan pendapat Taylor (Koentjaraningrat, 1985:12-13), yaitu jika orang telah mati, jiwa dan raganya terlepas selamanya. Jiwa mereka merdeka, bebas berbuat sekehendaknya. Alam semesta penuh dengan jiwa-jiwa merdeka seperti itu. Jiwa-jiwa tersebut tidak disebut soul (jiwa) lagi, melainkan spirit (makhluk halus). Spirit ini mempunyai posisi yang lebih kuat dibanding manusia yang masih hidup, karena mereka mampu mengontrol manusia, sebaliknya manusia pada umumnya tidak dapat melihatnya secara langsung. Itulah sebabnya, jika makhluk halus ini tidak mendapat perlakuan tertentu, orang Jawa takut jika mereka memberikan gangguan tertentu.

Senada dengan penafsiran demikian dalam buku-buku kuna milik orang Jawa, yakni Serat Kadilangu dan Serat Wali Sanga juga ada pemaknaan 
selamatan ke arah penyempurnaan jiwa dan raga manusia. Menurut kedua karya itu, makhluk hidup terdiri dari tubuh jasmani (slira), termasuk juga keinginan yang disebut kamarupa. Jasmani bisa bergerak karena adanya atma (semangat, energi), kama (keinginan) dan nafsu (prana). Manusia juga memiliki akal (manas), kecerdasan (manasa), dan jiwa. Apabila orang telah meninggal dan jasmaninya mulai membusuk, maka atma, kama, prana, manas, manasa, dan jiwa-nya mulai meninggalkan jasmani pada hari ketiga, tetapi masih diliputi oleh bentuk tubuh yang menyerupai bentuk asli, yang terdiri dari zat yang lebih halus dan ringan. Oleh karena itu tubuhnya dinamakan lingaselira (makhluk halus). Makhluk halus yang masih mempunyai keinginan ini dibimbing malaikat ke Kamaloka yang dicapai pada hari ketujuh. Akan tetapi ia harus melewati jembatan siratu mustakim. Jika yang bersangkutan mempunyai banyak dosa maka ia akan tercebur ke neraka. Jika amalnya baik, akan masuk ke Kamaloka pada hari ke-40. Sementara ia memurnikan dirinya pada hari ke-100. Ia baru akan sampai ke surga pada hari ke-1000. Selanjutnya akan berulang-ulang sampai menjadi sempurna mencapai surga ketujuh dan moksa (Koentjaraningrat, 1984: 336-338).

Pendapat demikian merupakan sinkretisme antara Hindu-Jawa dengan Islam. Dalam kepercayaan Hindu moksa adalah menjadi dambaan setiap umatnya. Bagian lain buku tersebut juga menyebut adanya idiom-idiom Islam seperti siratu mustakim. Kemungkinan karya tersebut menjadi pedoman penting dalam kehidupan masyarakat Jawa (pada zaman para wali) bahkan sampai sekarang masih ada yang melaksanakan.

\section{F. Nyatus dina atau Selamatan Setelah 100 Hari Kematian}

Cara menentukan waktu selamatan hari dan pasaran digunakan rumus perhitungan hari rosarma, yaitu hari kedua dan pasaran kelima. Jika ada orang meninggal dunia pada hari Jum' at Kliwon, maka selamatan nyatus dina jatuh pada hari Minggu Wage. Cara menentukan adalah dengan menghitung atau mencari Minggu Wage setelah hari kematian berjumlah (genap) tiga bulan. Setelah tiga bulan berarti sudah mencapai kira-kira 90 hari dan tinggal menentukan 10 hari lagi segera mencari hari Minggu Wage.

Tradisi selamatan nyatus dina dimaksudkan untuk menyempurnakan semua hal yang bersifat badan wadhag (Bratawidjaja, 1993:136). Di samping 
itu juga untuk memberikan penghormatan terhadap roh yang sudah berada di alam kubur. Di alam kubur ini, roh masih sering kembali ke dalam keluarga sampai upacara selamatan tahun pertama (mendhak pisan) dan peringatan tahun kedua (mendhak pindho).

Ubarampe selamatan nyatus dina sama dengan sajian selamatan nelung dina mitung dina, matangpuluh dina. Perbedaannya pada selamatan nyatus dina sudah menggunakan pasung, ketan, dan kolak. Pasung yang dibuat seperti gunung (payung) dari daun nangka dan diisi bahan dari gandum. Maknanya adalah agar yang meninggal mendapatkan payung (perlindungan). Karena orang yang meninggal akan melewati jalan panjang dan panas, maka untuk dia dibuatkan ketan sebagai alas (lemek) agar kakinya tidak panas. Ketan juga bermakna raketan artinya mendekatankan diri kepada Tuhan. Sajian juga dilengkapi kolak yang berasal dari kata khalik atau kolaq (pencipta). Dengan sajian semacam ini, diharapkan orang yang meninggal akan dengan lancar menghadap Sang Khalik.

Penafsiran semacam itu menunjukkan bahwa ada perpaduan antara Hindu-Jawa dengan Islam yang pada prinsipnya orang Jawa mempunyai dambaan untuk kembali kepada Tuhan dalam keadaan tata titi tentrem (tenang). Hal ini seperti halnya dikemukakan Geertz (1989:416) bahwa kondisi tenteram dan selamat adalah dambaan setiap individu dan masyarakat Jawa. Langkah untuk mencapai keselamatan yang selalu ditempuh adalah menjaga kesatuan kekuatan adikodrati, yakni bahwa dalam rangkaian kosmos itu dihuni oleh makhluk-makhluk seperti roh leluhur, dewa, jin, yang mbaureksa, lelembut, dhemit, thuyul, dan sebagainya. Makhluk-makhluk ini dimungkinkan berasal dari roh orang meninggal yang salah kedaden. Seperti halnya, jika ada orang Jawa yang mati konduran (meninggal karena melahirkan), mati menggantung diri, dan mati-mati yang lain yang tidak wajar. Masih ada yang percaya bahwa roh-roh orang mati tersebut akan berkeliaran (gentayangan) di sekitar manusia.

Uraian di atas menunjukkan bahwa tradisi selamatan kematian merupakan upaya untuk menghubungkan diri orang yang hidup dengan roh orang yang meninggal. Upaya ini menggambarkan bahwa sebagian masyarakat Jawa percaya bahwa roh orang yang telah mati itu masih "hidup" di alam 
semesta. Roh tersebut perlu dijaga dan diupayakan agar tidak mengganggu, bahkan diharapkan dapat mendatangkan kebahagiaan (Endraswara, 1998:4).

\section{G. Mendhak Sepisan atau Selamatan Setelah Satu Tahun Kematian}

Cara menentukan waktu selamatan hari dan pasaran mendhak pisan digunakan rumus patsarpat yaitu hari keempat dan pasaran keempat. Maksudnya jika ada orang meninggal dunia pada hari Jum' at Kliwon makan selamatan mendhak pisan jatuh pada hari Senin Pon setelah hari kematian genap satu tahun.

Ubarampe yang digunakan pada selamatan ini sama dengan selamatan nyatus dina. Fungsi selamatan ini adalah untuk menyempurnakan kulit, daging, dan jeroan (Bratawidjaja, 1993:136). Di samping itu juga mempunyai fungsi untuk mengingat-ingat kembali akan jasa-jasa orang yang telah meninggal. Ahli waris pada selamatan ini harus mengingat kebesaran almarhum/almarhumah. Karena itu selamatan mendhak pisan (nyetauni) sering disebut juga meling. Kata meling berasal dari kata eling artinya mengingatingat. Konsep mengingat-ingat juga terkandung pesan yang lain, yaitu sebagai upaya ahli waris untuk instrospeksi diri bahwa mereka pada saatnya juga akan dipanggil oleh Tuhan. Dengan cara ini mereka akan lebih berhati-hati dalam hidup dan akan meningkatkan amal perbuatan. Kecuai itu, mereka juga akan lebih yakin bahwa kematian adalah peristiwa khusus.

Hal demikian itu sesuai dengan tesis Hertz (Koentjaraningrat, 1985:2829) penganut tradisi meyakini bahwa orang yang telah mati memang ada hubungan khusus pula dengan ahli waris. Keyakinan ini menganggap (1) bahwa peralihan kedudukan sosial ke kedudukan sosial lain adalah suatu masa krisis, suatu masa yang penuh dengan bahaya gaib, tidak hanya bagi individu yang bersangkutan, tetapi juga bagi seluruh masyarakat; (2) anggapan bahwa jenazah dan juga semua orang yang ada hubungan dekat dengan orang yang meninggal itu dianggap mempunyai sifat keramat (sacre); (3) bahwa peralihan kedudukan sosial tadi tak dapat berlangsung sekaligus tetapi setingkat demi setingkat melalui masa antara yang lama; (4) anggapan bahwa upacara inisiasi harus mempunyai tiga tahap, yaitu tahap melepaskan si objek dari hubungan masyarakatnya yang lama, tahap yang mempersiapkannya bagi kedudukannya yang baru, dan tahap mengangkatnya ke dalam kedudukan yang baru; 
(5) bahwa pada persiapan masa inisiasi si objek merupakan seorang makhluk yang lemah sehingga harus dikuatkan dengan berbagai upacara ilmu gaib.

Dari pendapat itu dapat dimengerti bahwa orang yang telah mati memang memiliki kedudukan lain. Orang yang mati akan menempuh berbagai tataran atau tingkatan yang masing-masing tingkatan harus dipersiapkan betulbetul oleh ahli warisnya dengan cara mengirimkan doa dan selamatan.

\section{H. Mendhak Pindho atau Selamatan Setelah Dua Tahun Kematian}

Cara menentukkan waktu selamatan hari dan pasaran mendhak pindho digunakan rumus jisarlu, yaitu hari kesatu dan pasaran ketiga. Cara menghitung adalah setelah satu dua tahun dari hari kematian (geblag) dicari pada bulan yang sama dengan pada waktu meninggalnya. Jika ada orang yang meninggal pada hari Jum' at Kliwon berarti mendhak pindho jatuh pada hari Jumat Paing.

Selamatan mendhak pindho dimaksudkan untuk menyempurnakan semua kulit, darah dan semacamnya. Pada saat ini jenasah sudah hancur luluh, tinggal tulang saja (Bratawidjaja, 1993:136). Pada saat ini juga dilakukan pengiriman doa dengan cara tahlil dan sajian selamatan. Ubarampe selamatan sama dengan selamatan sebelumnya.

Tradisi selamatan kematian sangat mungkin merupakan hasil akumulasi kepercayaan masyarakat Jawa dengan kepercayaan lain, seperti adanya pengaruh Hindu, Buda, dan Islam. Akibat dari pembauran kepercayaan ini dinamakan sinkretisme Jawa (Sujamto, 1992:13-15). Hal ini seperti halnya juga dikemukakan Geertz (1989:529) bahwa di Jawa sering terjadi manifestasimanifestasi Islam sinkretik dalam arti, umpamanya, kepercayaan dan ritualritual Jawa tetap dipertahankan sebagai ritual Islam setempat. Hasil sinkretik itu telah mewarnai kehidupan masyarakat Jawa sehingga hampir sulit dipisahkan antara kepercayaan asli dan kepercayaan yang mempengaruhinya.

\section{Nyewu atau Selamatan Setelah Seribu Hari Kematian}

Cara menentukan waktu selamatan hari dan pasaran seribu hari (nyewu) digunakan rumus nemsarma yaitu hari keenam dan pasaran kelima. Cara menghitung dengan menentukan hari setelah waktu kematian setelah menjelang tiga tahun atau setelah kurang lebih 2 tahun 10 bulan segera dicari 
hari yang cocok. Jika meninggal hari Jumat Kliwon selamatan nyewu jatuh pada hari Rabu Wage.

Nyewu boleh dikatakan sebagai puncak dari rangkaian selamatan kematian. Pada saat ini orang Jawa meyakini bahwa roh manusia yang meninggal sudah tidak akan kembali ke tengah-tengah keluarganya lagi. Roh tersebut betul-betul telah akan meninggalkan keluarga untuk menghadap Tuhan. Itulah sebabnya selamatan pada saat ini dilaksanakan lebih besar dibanding selamatan sebelumnya. Karena itu untuk pembacaan kalimah tayibah (tahlil) pun peserta yang diundang juga jauh lebih banyak. Jika sebelumnya tidak memakai makanan sesudah tahlil, biasanya selamatan nyewu memakai makan bersama. Setelah makan bersama lalu dilaksanakan kenduri.

Selamatan nyewu ini, biasanya, ditandai dengan upacara ngijing atau nyandhi. Untuk mengganti patok yang setelah tiga tahunan mestinya sudah mulai rusak. Kijing yang digunakan berasal dari bahan kayu, bukan dari batu. Hal ini sebagai tanda agar anak cucunya nanti mau menggantikannya. Dengan cara menggantikan itu mereka akan menjadi ingat pada leluhur yang telah mati. Berbeda dengan kijing yang dibuat dari batu yang sangat mungkin selamanya tidak akan rusak atau diganti.

Ubarampe selamatan pada saat nyewu memang ada yang sama dengan selamatan sebelumnya. Namun ada sedikit kekhususan yaitu pemakaian ubarampe yang berupa penyembelihan kambing. Kambing yang disembelih diupayakan sama dengan kambing yang disembelih pada saat geblag. Kambing ini dimaksudkan sebagai tumpakan roh orang yang mati agar selamat melewati wot siratolmustakim.

Ubarampe selamatan yang lain yang menunjukkan bahwa hubungan roh dengan keluarga sudah pisah, adalah pemakaian pisang raja satu sisir yang diikat dengan benang putih. Benang tadi oleh kaum pada saat memimpin doa (ngekralke) diputus menggunakan gunting. Pemutusan ini menandai bahwa sudah tidak ada hubungan lagi antara roh orang yang meninggal dengan keluarga. Kecuali itu juga digunakan ubarampe merpati putih bagi keluarga yang lebih mampu. Merpati itu lalu diterbangkan ke angkasa setelah selesai selamatan. Hal ini berarti seagai tanda bahwa roh orang yang mati telah pergi jauh atau telah lepas parane, pulang ke alam kelanggengan.

Selamatan nyewu juga sering dinamakan selamatan mendhak ketiga. 
Fungsinya adalah untuk menyempurnakan rasa dan bau orang yang mati sehingga semua rasa dan bau lenyap (Bratawidjaja, 1993:136). Karena itu, setelah nyewu jika ada keluarga yang lain meninggal sudah boleh dikebumikan di dekatnya. Maksudnya bahwa jasat orang yang mati sebelumnya andaikata digali di dekatnya sudah tidak ada bau apa-apa.

Uraian di atas tampak bahwa pelaksanaan selamatan memang ada percampuran kepercayaan antara Hindu-Jawa dengan Islam. Dalam hal ini ditandai dengan penggunaan doa-doa dan tahlil secara Islam namun di balik itu mereka juga masih membakar kemenyan dan membuat saji-sajian. Kepercayaan Hindu-Jawa ini dalam konsep religiusitas Jawa sering dinamakan sinkretisme Jawa (Sujamto, 1992:13). Istilah sinkretisme dalam kamus Antropologi (1985:373) diberi arti sebagai "kombinasi segala unsur dari beberapa agama dan kepercayaan yang berbeda, kemudian terpadu menjadi satu yang kemudian merupakan agama atau kepercayaan versi baru".

Secara keseluruhan para penganut sinkretisme itu kebanyakan adalah kaum abangan. Hal ini sesuai dengan pendapat Koentjaraningrat (1984:209) bahwa pelaksanakaan selamatan sebenarnya timbul karena didorong oleh sistem kepercayaan masyarakat Jawa, terutama yang dilakukan oleh kaum abangan. Kaum abangan adalah kontras dari penganut kaum putihan (penganut Islam murni). Kaum abangan biasanya kurang serius dalam menjalankan agama Islam dan lebih ke arah campuran dengan kepercayaan.

\section{DAFTAR PUSTAKA}

Bratawidjaja, Thomas Wiyasa. 1993. Upacara Tradisional Masyarakat Jawa. Jakarta: Sinar Harapan. 1997. Mengungkap dan Mengenal Budaya Jawa. Jakarta: Pradnya Paramita.

Endraswara, Suwardi. 1998. Ritus dan Kepercayaan Masyarakat Jawa. Yogyakarta: Makalah, tidak dipublikasikan.

Geertz, Clifford. 1987. Keyakinan Religius dan Perilaku Ekonomi di Sebuah 